\title{
Cereal leaf beetle: is performance affected by grass endophytes?
}

\author{
S.L. CLEMENT ${ }^{1}$, L.R. ELBERSON ${ }^{1}$, T. MILLER ${ }^{2}$, M. KYNASTON ${ }^{1}$ and T. D. PHILLIPS ${ }^{3}$ \\ ${ }^{I}$ USDA, ARS, Washington State University, Pullman, WA 99164-6402 USA \\ ${ }^{2}$ Department of Entomology, Washington State University, Pullman, WA 99164-6382 USA \\ ${ }^{3}$ Department of Plant and Soil Sciences, University of Kentucky, Lexington, KY 40546-0312 USA
}

Cereal leaf beetle (CLB), Oulema melanopus (L.) (Coleoptera: Chrysomelidae), a long known pest of small grains in Europe, was first recorded in North America (Michigan) in 1962. It now occurs in many USA regions including the Pacific Northwest, where it first appeared in the late 1990s. Wheat, oats, and barley are susceptible to CLB adult and larval feeding damage. Although several forage grasses (i.e. fescues, ryegrasses) are CLB host plants in the literature, and heavy infestations have been found in a tall fescue (Festuca arundinacea) field in Oregon (USA), little quantifiable data exists on CLB performance on these grasses. We investigated the influence of different forage grass - Neotyphodium endophyte associations on CLB feeding and development, thereby expanding knowledge of anti-insect properties of endophyte-infected $(\mathrm{E}+)$ forage grasses and the host suitability of these grasses for CLB. In glasshouse experiments, equivalent $(\mathrm{P}>0.05)$ adult $\mathrm{CLB}$ feeding damage was recorded on $\mathrm{E}+$ and $\mathrm{E}-$ tall fescue and perennial ryegrass (Lolium perenne) plants, and female beetles readily laid eggs on E+ and E- plants. Larval development to the $4^{\text {th }}$ instar averaged 22.3 and 21.5 days $(\mathrm{P}>0.05)$, respectively, on $\mathrm{E}+$ and E- Kentucky 31 tall fescue, compared to 15.4 days on barley. These preliminary findings suggest that tall fescue and perennial ryegrass are good CLB host plants, but the beetle's performance is not adversely affected by some grass-endophyte associations.

Keywords: Neotyphodium endophyte, tall fescue, perennial ryegrass, insect resistance, cereal leaf beetle, Oulema melanopus 